重複胃に拈ける早期癌と胃癌を合併した 1 例

\author{
旭川医科大学第 1 外科 \\ 石川 雅彦 䚗島 夏樹 \\ 旭川赤十字病院外科 \\ 松下 元夫 柴野 信夫 菱山四郎治
}

\title{
A CASE OF EARLY CANCER OF THE DUPLICATED STOMACH ACCOMPANIED WITH GASTRIC CANCER
}

Masahiko ISHIKAWA and Natsuki SAMEJIMA

The First Department of Surgery, Asahikawa Medical College

\section{Motoo MATSUSHITA, Nobuo SHIBANO and Shirouji HISHIYAMA}

Department of Surgery, Asahikawa Red Cross Hospital

象引用語：消化管重複症, 胃重複症, 胃襄腫

はじめに

消化管重複症は比較的まれな疾患であり，重複胃は さらにまれとされている1) . われわれは本来の胃に 癌性病変を認め, 重複胃が合併し,さらに後者の粘膜 に早期癌を認めた症例を経験したので若干の文献的考 察を加えて報告する。

\section{症例}

患者：57歳，男性。

主訴：体重減少。

家族歴：母親が肝葴癌で死亡。

既往歴：特記すべきことなし。

現病歴：昭和 60 年 3 月頃より食欲不振となる。6月 頃になると悪心，呕吐出現し，体重が 1 カ月間に約 $4 \mathrm{~kg}$ 减少し，6月17日旭川赤十字病院内科受診. 精査にて 胃前庭部に隆起性病変を認め, 手術目的のため 6 月 24 日外科入院となった。

入院時現症：体格は中等度，栄養は不良で貧血を認 めるす黄㾝はなかった，胸，腹部，四肢に特に異常を 認めず，表在リンパ節も触知しなかった。

入院時検查所見: WBC $7,070 / \mathrm{mm}^{3}, \mathrm{RBC} 373 \times$ $10^{4} / \mathrm{mm}^{3}, \mathrm{Hb} 11.6 \mathrm{~g} / \mathrm{dl}, \mathrm{Ht} 34.1 \%$ と軽度の負血を認 めたが, 血液生化学的検查や腫演、ーカーには異常を 認めなかった。

胃 $\mathrm{X}$ 線検査所見：幽門前庭部に不規則な陰影欠損

$<1988$ 年 4 月13日受理 >別刷請求先：石川 雅彦

干078-11旭川市西神楽 4 線 5 号 旭川医科大学第 1 外科
像および幽門狭窄像を認めた。

胃内視鏡所見：X線像に一致し，胃幽門前庭部に Borrmann 3 型の隆起性病変が認められ, 同部位の生 検にて adenocarcinoma と診断された。

腹部 computed tomography（以下 CT) 所見：胃底 部後壁および膵尾部に接して直径約 $9 \mathrm{~cm}$, 円形で, 比較 的境界明瞭な low density area を認めた（図 1 ). 以 上により胃腫瘍による幽門狭窄および膵要胞の診断に て，7月4日手術を施行した.

手術所見：上腹部正中切開にて開腹. 腹水なく, 肝 臓, ダグラス窩には異常を認めなかった。胃前庭部の 病変は浆膜側からはっきりと触知され, $\mathrm{S}_{2} \mathrm{H}_{0} \mathrm{P}_{0} \mathrm{~N}_{2}$ Stage III であった。 また, 術前脺変胞と思われたもの は胃底部後壁より浆膜側への突出した衰胞状腫瘤と判 明した。この腫瘤は膵蔵や脾藏とは交通していなかっ た. また，所属リンパ節の腫脹を認めたため，手術は 覆胞状腫瘤を含めて第 2 群リンパ節郭清を伴う胃全摘 術を施行した。

摘除標本所見：亭腫は胃底部後壁より突出して存在 し，大きさは $10.0 \times 9.0 \times 9.0 \mathrm{~cm}$ であった。摘除した胃 を小弯側切開すると幽門前庭部に大きさが $8.0 \times 8.0 \times$ $1.5 \mathrm{~cm}$ の Borrmann 3 型の腫場性変化が認められた （図 2). 琼腫を切開すると，内部は灰白色の泥状物で 占められ，峦腫内腔と胃内腔は交通はなく，完全に分 離していることが判明した(図3). また, ホルマリン 固定後に亳腫内腔を観察すると, 雯腫粘膜の一部に大 きさ $0.7 \times 0.7 \times 0.5 \mathrm{~cm}$ の中心陥凹を伴 5 隆起性病变 
図 1 腹部 CT 像, 胃底部後壁之膵尾部に接する低吸 収域を認める。

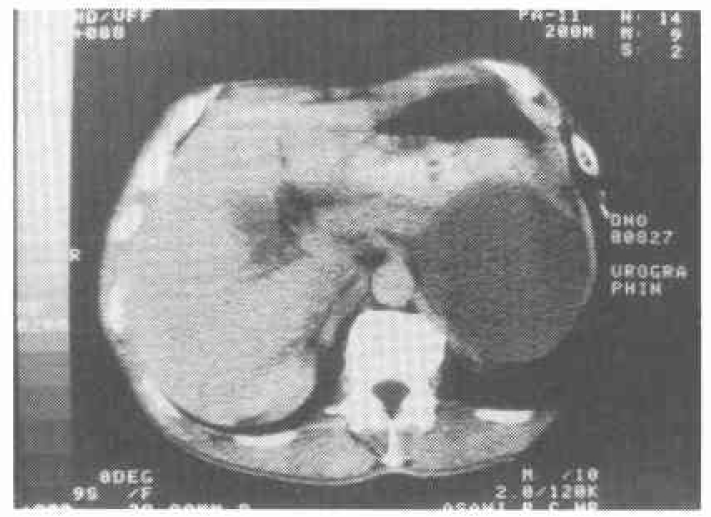

図 2 摘除標本像. 胃底部後壁に囊腫性病変々幽門前 庭部に Borrmann 3 型の腫族性変化を認める.

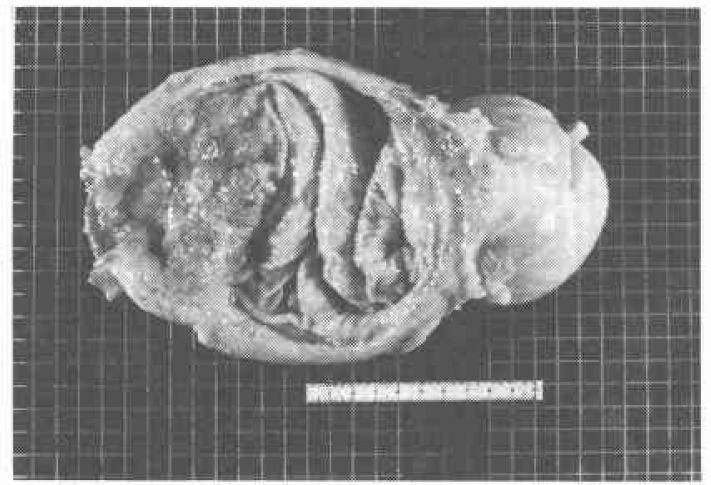

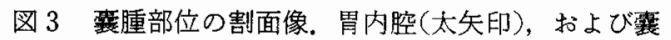
腫内腔 (細矢印) を示す.

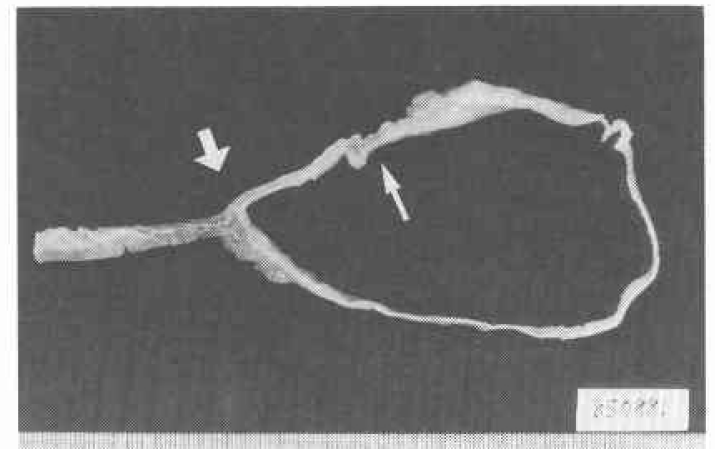

が認められた（図 4).

組織学的所見：幽門前庭部の腫湟性変化は深達度 ss $\gamma$ の poorly differenciated adenocarcinoma であ
図 4 霊腫内腔像，中心陥凹を伴う隆起性病変を認め る(矢印)。

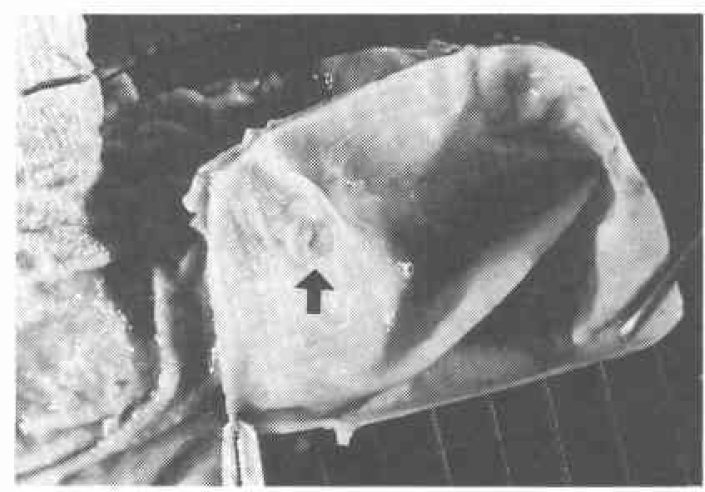

図 5 隔壁部位の病理組織像. 胃内腔(太矢印)，拈よ び而腫内腔（細矢印）を示す。

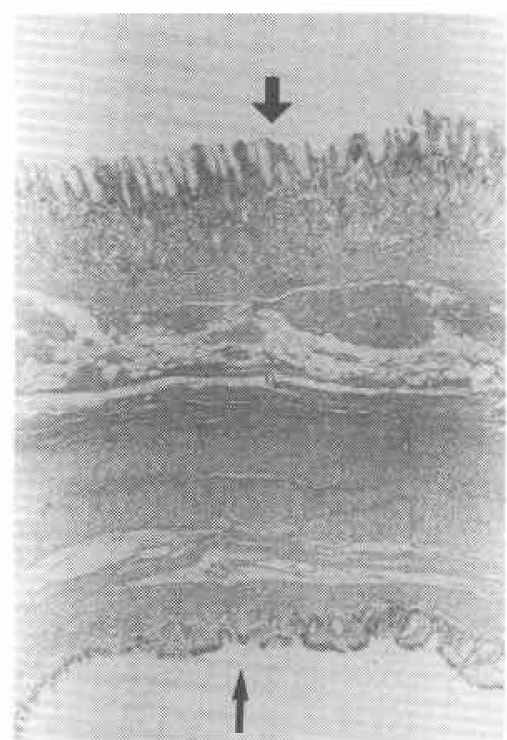

り, 所属リンパ節転移も認めた $\left(\mathrm{n}_{2}(+)\right)$. また, 霊腫 と胃内腔との隔壁を観察すると両者は平滑筋層を共有 し, 震腫の粘膜は胃粘膜に類似しており，大部分が円 柱上皮で覆われ，一部に高円柱上皮, 多列繊毛上皮や 幽門腺様組織も認められた(図 5 )。襄腫壁の構造は一 様でなく，一部では粘膜や筋層がきわめて薄い部分も 存在していた。以上のことから,この䨓腫は胃重複症 と診断された。 また, 震腫内の小隆起性病変は深達度 $\mathrm{m} の$ well differenciated adenocarcinomaであった (図6).

術後経過：患者は第32病日に退院した。術後約 2 年 
図 6 雯腫内隆起性病変の病理組織像. 深達度 $m$ の高 分化型腺癌を認める.

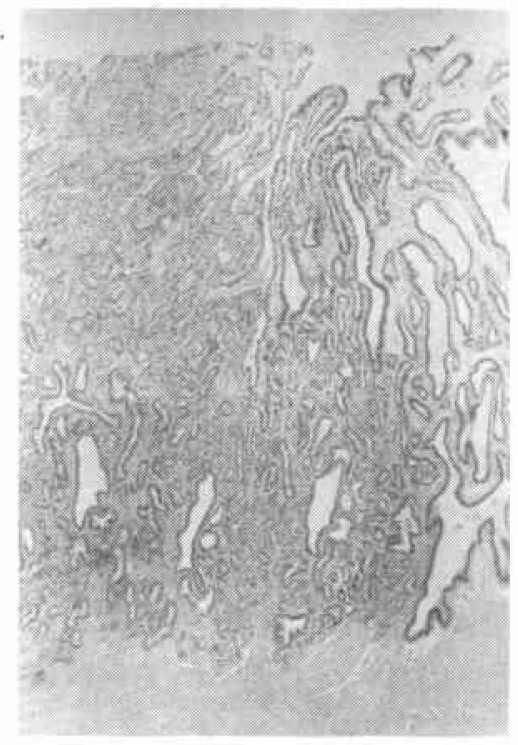

4 カ月後の現在, 再発や遠隔転移は認められず元気に 外来通院中である。

\section{考察}

消化管重複症は舌から肛門までの全消化管に発生し らる先天性疾患であり，1940年 Ladd \& Gross ${ }^{11}$ が, “duplication of the alimentary tract”と呼ぶことを提 唱した．本症の定義は Ladd \& Grossによると，(1)平 滑筋層を有する, (2)内面が消化管粘膜で覆われている, (3)正常消化管に隣接し，それと筋層を共有する，とさ れている。しかし，この定義は胸部消化管重複症には 適用され難く，中には主腸管と離れて存在し，しかも 消化管粘膜に覆われ，固有の平滑筇層を持つ症例もあ ることから²), 現在では，(1)，(2)のみです消化管重複症 と診断してよいと解釈されるようになっだ).

消化管重複症の発生部位別頻度では胃重複症の発生 頻度は低く, Gross 5 4)は2.9\%(2/68), 軍司 ら²)は $10.4 \%(33 / 316)$, 石田ら ${ }^{5}$ は $8 \%(5 / 64)$, 長嶺ら ${ }^{6)}$ は $6.6 \%(12 / 180)$ と報告している.

胃重複症の本邦報告例は自験例を含めて，涉孜しえ た範囲では約50例前後の報告があるが，同種の形態を 有する症例が一方では消化管重複症として報告され， 他方では消化管露腫として報告されたりすることもあ $\eta^{738)}$ ，また，Grossの定義と異なる症例もあることか $5^{9)}$, 実際の総数はさらに多くなることが予想される. 消化管重複症の形態は長嶺ら ${ }^{6}$ は管状と球状に分類
し，胃重複症では球状のるのがほとんどであるとして いる，また，池田らフは，筋層の共有の有無による分類 を試み，筋層を共有するすのを非分離型，共有しない ものを分離型とし，胃重複症では非分離型が大部分を 占めるとさている。これらによると自験例では球状, 非分離型の胃重複症といらことになる。

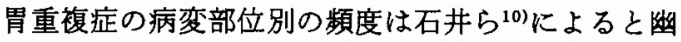
門洞大弯 $(27.8 \%)$, 体部大弯 $(13.9 \%)$, 前庭部大弯 (11.1\%)，と大弯での発生が52.8\%にみられており， 他に小弯 $(8.0 \%)$ での発生や胃に接しないもの，他の 消化管に接しているものなどがあるとしている.

年龄，性別に関しては胃重複症が先天性疾患である ことから, Bartels ${ }^{11}$ によと約70\%をでが幼少児期に 発症していて，男女比は6：4で男に多いとされてい るが，本邦例では小児例は $52 \%$ で成人例と差がなく， また，女性に多い傾向がある10).

症状は発生部位，大きさ，年龄によって異なり，本 来の胃との交通のない場合は無症状に程過し, 胸部 X 線検查や上部消化管造影検査にて偶然発見されること も多(2)101. 一般的には小児では腹部腫瘤, 呕吐を主訴 とすることが多く2，成人では上腹部痛，上腹部不快感 など不定愁訴が多いとされている10). また, 球状で胃壁 に密接している症例では胃の圧排や閉塞による症状が 出現したり，㘊腫内圧の上昇による粘膜面のびらんゃ 潰瘍を形成し，出血や穿孔による症状が生ずることも ある12)13). 本症例では本来の胃に存在した悪性病変に よる症状がでているが，栾腫による王迫，閉塞などの 症状は認めなかった。

診断に関しては, 術前に胃重複症と診断された例は 少なく，上部消化管造影検査にて正常腸管の王排所見 や重複腸管像を認めることもあるが，その頻度は少な い. 最近, 画像診断の進歩により CT 検査 ${ }^{14)}$ や超音波検 查 $^{15)}$ により歪腫状病変が確認され，本症の診断に有用 とされているが，それが重複胃か否かの判別，つまり

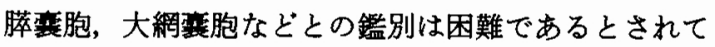
いる. 本症例も術前の腹部 CT 検查にて胃底部後壁と

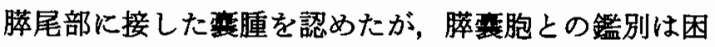
難であった。また，重複胃内にしばしば存在する異所

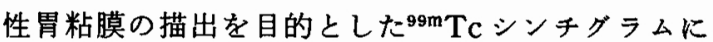
よって，多発性消化管重複症を診断した症例も報告さ れていることから゙，比較的有用な検査と考劣られた。

消化管重複症の悪性化の危険性に関しては黣島 ${ }^{16)}$ に よってすでに指摘されているが, 本邦報告例では重複 十二指腸早期癌の 1 例17)のみであり，重複胃に悪性病 
変が存在した例はいまだ報告例を認めない，欧米では 消化管重複症に癌が発生していた例は文献検索しえた

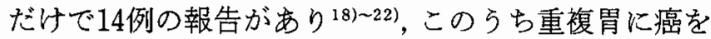
合併した例は 1 例だけで認められた ${ }^{23)}$.しかし，自験例 の様に本来の胃に Borrmann 3 型の胃癌を認め, さら に重複胃の内部粘膜に早期癌を認めた例はいまだ報告 例はなく，きわめてまれな症例と考克られた。

消化管重複症に打ける癌の発生機序に関して論じた 報告はないが，胃の輍胞性病変と癌との関連について はいくつかの考察がある，岩永ら ${ }^{24)}$ は胃囊胞粘膜はび らん, 再生が繰り返されやすく, 癌化しやすいとし, 井口ら ${ }^{25)}$ は襄腫壁の細胞に異型性を認めることから胃 の囊胞性病変は前癌病変であるとしている。

いずれにしても癌の発生は消化管重複症の重篤な合 併症の 1 つであり，常に注意深く検索することが大切 と考克られた。

治療は症例により最も適当な術式をとるのがよいと されているが12), 胃重複症では重複胃と本来の胃との 剥離が困難なためか重複胃を含めた胃切除術を行った 例が最も多(2)316). 一般的に消化管重複症では腸管壁 に密接し，同一血管支配下にあるものは囊腫を含めて の消化管切除が望ましいとされている2)3． また，文献 上では脊䯣などの合併奇形や合併重複症の報告例も多 く3(6)12)，これらのことに関しても注意をはららべきで あると考えられた。

\section{結 語}

胃の前庭部に Borrmann 3 型の胃癌を認め, 重複胃 を合併し，さらに後者の粘膜に早期癌を認めた 1 例を 報告し，若干の文献的考察を加えた。消化管重複症は 比較的まれな疾患であるが粘膜に悪性病变を合併する こともあり，注意深く検索する必要があると考兄られ た.

\section{文 献}

1) Ladd WE, Gross RE: Surgical treatment of dupulications of the alimentaly tract. Surg Gynecol Obstet 70:295-307, 1940

2）軍治祥雄, 竜 崇正, 石川達雄活加：胆道系之交通 を有する特異な重複胃の 1 治験例。臨外 $36: 139$ $-145,1981$

3）福重隆彦, 水田祥代, 池田恵一ほか：多発性消化管 重複症の 1 例。日小児外会誌 $18: 87-92,1982$

4) Gross RE, Holcomb GW, Farber S: Duplication of the alimentary tract. Paediatrics 9 : 449-468, 1952

5）石田正統，土田嘉昭，斉藤純夫注か：消化管重複
症. 外科診療 $9: 216-226,1967$

6）長嶺信夫，宮城 靖，遠藤 㦑汪か：消化管重複 症. 外科䛦療 $19: 466-471,1977$

7）池田光則, 佐藤元通, 東権 広㳗加：消化管重複症 の2 例。小览外科 $15 ： 95-99,1983$

8）積 惟貞, 遠藤良一, 渡部秀一汪か：胃喜腫の 3 例。秋田医師会誌 $27: 31-37,1975$

9）日下典子, 西城秀郎, 天野信一㳗加：異所性胃重複 症の 1 例。三重医 $25: 42-44,1981$

10）石井 純, 河野秀親, 大塚宗臣注か：胃重複症の 1 例。消外 $10: 1015-1019,1987$

11) Bartels RJ : Duplication of the stomach. Am Surg 33:742-752, 1967

12）伊藤喬広, 長屋孝美, 杉藤徹志《か：小児の胃重複 症。小児外科・内科 $4: 221-229,1972$

13）島田寛治：成人の胃重複症の 1 治験例。胃之腸 $11: 1135-1140,1976$

14) Laurence MW, Fagelman D, Warhit MW : CT demonstration of an esophageal duplication cyst. J Comput Assist Tomogr 7:716-718, 1983

15) Sarti D: Ultrasonic evaluation of abdominal gastrointestinal tract duplication in children. Radiology 109: 191-194，1979

16）鮫島夏樹：先天性樅隔震腫について。外科治療 $30: 353-363,1974$

17）井上雅勝，田中 繁, 阿部重郎俰か：胆震欠損を 伴った重複十二指腸早期癌の 1 例。日消外会誌 $11: 384-388,1978$

18) Butler CL, Ende M: Double esophagus with carcinoma in one. Arch Pathol 49:605-611, 1950

19) Bovin Y, Cholette JP, Lefebvre R: Accesory esophagus complicated by an adenocarcinoma. Can Med Assoe J 90 : 1414-1417, 1964

20) Orr MM, Edwards J: Neoplastic change in duplication of alimentary tract. Br J Surg 62 : 269-274, 1975

21) Downing R, Thompson H, Williams A : Adenocarcinoma arising in a duplication of the rectum. Br J Surg 65:572-574, 1978

22) Chuang MT, Barba FA, Kaneko M : Adenocarcinoma arising in an intrathoracic duplication cyst of foregut origin. Cancer 47 : 1887-1890, 1981

23) Mayo HW, McKee EE, Anderson RM: Carcinoma arising in reduplication of the stomach. Ann Surg 141：550-555, 1954

24）岩永 㓮，谷口春生：多発性胃壁内衰腫と胃癌々 の関保。医のあゆみ $84: 492-493 ， 1973$

25）井口公雄, 松本仁志，石橋治昭注か：重複胃癌を合 併した多発性胃粘膜下囊腫の 2 例について。日外 会誌 $81 ： 688-693,1980$ 